\title{
The Effect of Green Marketing Mix On Green Consumer Behavior and Green Purchasing Decision
}

\author{
Lili Karmela Fitriani ${ }^{1}$, Entin Jumantini ${ }^{2}$, Odang Supriatna ${ }^{3}$, Jaelani4 \\ Kuningan University, Indonesia \\ \{lili@uniku.ac.id', jumantinie04@gmail.com², odangs14@gmail.com³ $\}$
}

\begin{abstract}
The research explores the effect of marketing mix on consumer behavior to buy environmentally friendly products - this research was conducted on AQUA, a mineral water brand. Green marketing and green product concepts have become the focus of attention from people in business to retaining consumers. The sample of the research is 147 people - the data analysis used SEM. The result indicates that Green Marketing Mix Affects Green Consumer Behavior significantly. Green Consumer Behavior affects Green Purchase Intention. Green Marketing Mix does not impact the Green Consumer Intention. Green Consumer Behavior and Green Purchase Intention affect the Green Purchase Decision.
\end{abstract}

Keywords: Green marketing mix; green consumer behavior; green purchase intention; green purchase decision

\section{Introduction}

Climate change and environmental damage have changed the way businesses run. This leads to the emergence of green marketing. Industrialization increases pollution resulting in non-environmentally-friendly products. As a result, consumers start to adjust their lifestyle to the green consumer's concept, where they believe in the importance of preserving and protecting the natural environment. This consumer's awareness causes an increase in the demand for environmentally friendly products. Green marketing can motivate consumers to buy environmentally friendly products[1]. According to[2] green product and green promotion impact consumer purchasing behavior for environmentally friendly products. Whereas [3] explained that green product and green placement do not impact consumer satisfaction; green promotion and green prices result in consumer satisfaction. Research by [4] explains that the green marketing mix impacts consumer purchasing behavior significantly. Likewise, according to[5], the green marketing mix has a significant effect on purchasing environmentally friendly products.

Bottled drinks market share reaches 84 percent, dominated by several big brands; one of them is Aqua with $46.7 \%$ market share[6]. The use of plastic bottles is increasingly prevalent among people. The use of plastic bottles can be a threat to the environment.

\section{Literatur Review}

\subsection{Green Marketing Mix}

[7]Explains that environmentally friendly marketing is the efforts of a corporate organization to design, promote, set the price, and distribute environmentally friendly 
products. [8], [9] defines green marketing as all of the designed activities to produce and facilitate any exchanges intended to fulfill people's needs or desires, so the satisfaction of these needs and desires occurs, with minimal adverse impacts on the natural environment. Lozada (2000) defines green marketing as an application of marketing tools to facilitate change by ensuring organizational satisfaction and individual goals to maintain, protect, and preserve the physical environment [10] defines green marketing as a holistic and strategic responsibility. This definition refers to a management process that identifies, anticipates, satisfies, and fulfills stakeholders' needs to provide recognition without damaging humans or the natural environment. [11] mentions the dimension of green marketing by integrating the environment into every marketing aspect, such as developing green products and green communication.

The Green marketing mix includes developing and applying prices, motives, and distribution strategies specifically designed to promote and preserve environmental welfare. Companies are forced to implement ecologically friendly policies to produce products, channels, prices, advertisements, and product placement in the market [12]. [13] Identify Green products as products produced by having environmental awareness, having a minimum level of environmental effects, products, or packaging made from recycled materials, preserved from natural resources and produced locally. A green product is a product that does not pollute the earth or deplete natural resources and could be recycled or retained its value. Green products are expected not to threaten human or animal health and not cause environmental damage [14].

Green price refers to the amount paid by an individual who orders to get environmentally friendly products (Burrow, 2008). Consumers will pay a higher price because the benefits of consuming environmentally friendly products are higher than the cost [15]. The green place is associated with effective product positioning. Green channel choice selects a channel place or location which minimizes the environmental damage and makes a product available, so it has a significant impact on consumers [16]. Green promotion is a promotion movement that took up about the relationship between products/services and the biophysical environment, promotions that promote an environmentally friendly lifestyle by highlighting products or services and promotions that provide a corporate image of environmental responsibility [16] ; [17] Green promotion is one of many ways to promote environmentally friendly products. According to [18], advertisement is very useful in increasing consumer knowledge about the environment and environmentally friendly products [18].

H1: Green marketing mix affects green consumer behavior

\subsection{Green Consumer Behavior}

Consumer behavior is the study of the processes involved when individuals or groups choose, buy, and use the products, services, ideas, or experiences to meet their needs and desires[19] Green consumers are defined as those who actively seek out and support the products that satisfy their requirements and have a minimum impact on the environment [11]. If they are faced with a choice between two identical products, they will prefer an environmentally friendly product [20]. According to [5], Green marketing has a significant correlation with green consumer behavior. Green consumer behavior of an individual whose behavior is influenced by his concern for the environment is reflected by how the individual searches for, buy, uses, evaluates, and disposes of the product [21].

H2: Green Consumer Behavior affects Green Purchase Intention 


\subsection{Green Purchase Intention}

Purchasing interest is consumers' tendency to buy a brand or take action related to the purchase measured by the likelihood of consumers making a purchase (Assael, 2004). Purchase intentions can be translated into green behavior when consumers believe that their efforts to consume environmentally friendly products positively affect [22]. [23] Someone with a positive intention to buy green products, shows a higher level of actual purchase than people who have a low intention or no intention to buy environmentally friendly products [24]. Several previous studies that related to green purchase intention have identified environmental awareness as an essential antecedent of consumer intentions [25]; [26] [27]

H3: Green Marketing Mix Affects Green Purchase Intention

\subsection{Green Purchase Intention}

There is a gap between environmental trust and green consumer behavior. Consumers are not likely exposed to an advertisement if they are very aware of more significant green products and green marketing to encourage consumers to adopt friendly behaviors. Those who are environmentally conscious will prefer environmentally friendly products [20]. Customers will not buy environmentally friendly products if the products have low quality and high prices. Customers will prefer to choose to buy a product that has been used before. The experience will also shape the purchasing behavior of environmentally friendly products from customers. This means that price is crucial in environmentally friendly purchasing behavior and product quality [28]. Consumer purchasing decisions for environmentally friendly products are mostly based on environmental concerns, values, and interests [29].

\section{Methodology}

The sample of this research was 152 people. Sampling collection technique with purpose sampling with community criteria with a minimum age of 15 years and have consumed AQUA. After confirming and normality testing, it turned out only 147 questionnaires that could be used for the analysis, using SEM with AMOS 21 software.

\section{Results and Discussion}

Confirmatory test results from 18 indicators show only ten indicators to analyze the research model. Four indicators for Green Marketing Mix, two indicators for Green Consumer Behavior, two indicators for Green Purchase Intention, and two indicators for Green Purchase Decision. Figure 1 shows the full model testing. It shows (goodness fit index) $\chi^{2}=42,550$, Probability $=0,064$, TLI $=0,984$, CFI $=0,989$, GFI $=0,944$, AGFI $=0,898$, DF $=30$, $\mathrm{CMIN} / \mathrm{DF}=1,418$, and RMSEA $=0,054$. While Table 2 shows the hypothesis test, the significance probability is lower than $5 \%$ for each relationship between the hypothesized variables. This concludes that from 5 hypotheses, only four hypotheses were supported by sample data, and 1 hypothesis was rejected. 


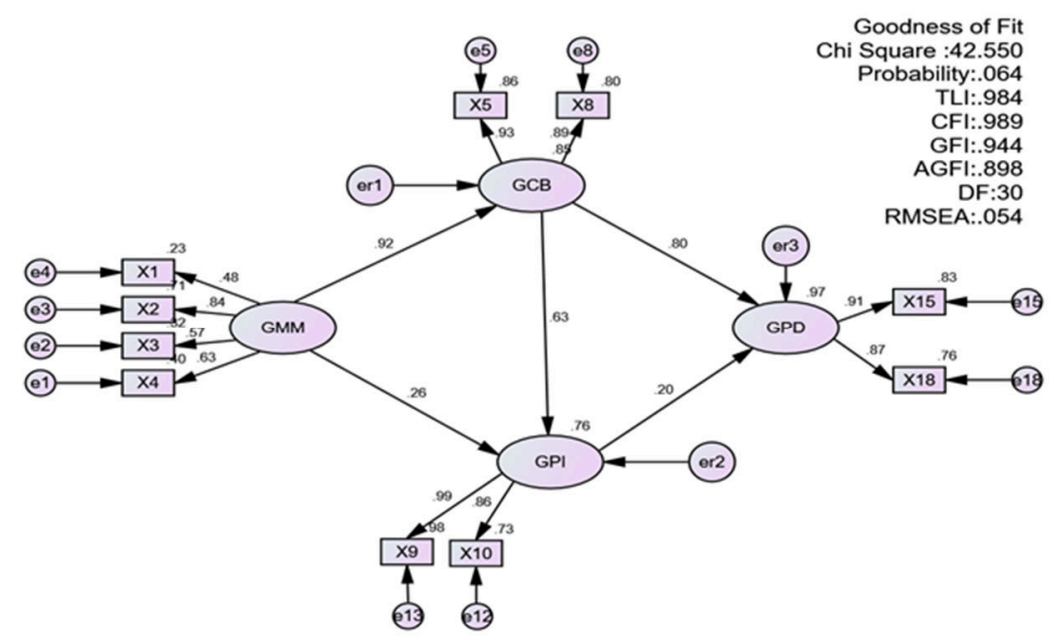

Fig 1. The Full Model

Table 1. Hypothesis test

\begin{tabular}{cccccc}
\hline \multicolumn{2}{c}{ Causality relationship } & $\begin{array}{c}\text { Standardized } \\
\text { Estimate }\end{array}$ & P & Information \\
\hline $\begin{array}{c}\text { Green } \\
\text { Marketing Mix } \\
\text { Green }\end{array}$ & $\rightarrow$ & $\begin{array}{c}\text { Green Consumer } \\
\text { Behavior }\end{array}$ &, 922 &, 000 & Supported \\
$\begin{array}{c}\text { Consumer } \\
\text { Behavior } \\
\text { Green }\end{array}$ & $\rightarrow$ & $\begin{array}{c}\text { Green Purchase } \\
\text { Intention }\end{array}$ &, 630 &, 004 & Supported \\
$\begin{array}{c}\text { Marketing Mix } \\
\text { Green }\end{array}$ & $\rightarrow$ & $\begin{array}{c}\text { Green Purchase } \\
\text { Intention }\end{array}$ &, 255 &, 253 & Not supported \\
$\begin{array}{c}\text { Consumer } \\
\text { Behavior } \\
\text { Green } \\
\text { Purchase }\end{array}$ & $\rightarrow$ & $\begin{array}{c}\text { Green Purchase } \\
\text { Decision }\end{array}$ &, 803 &, 000 & Supported \\
Intention & $\rightarrow$ & $\begin{array}{c}\text { Green Purchase } \\
\text { Decision }\end{array}$ &, 203 &, 047 & Supported \\
\hline
\end{tabular}

\section{Conclusion}

Hypothesis 1 is accepted. It states that there is a significant effect of green marketing mix on green consumer behavior. The higher the public perception of the green marketing mix, the higher the green consumer behavior towards the environmentally friendly AQUA product. This study's results are consistent with the research conducted by [5], which states that green marketing has a significant correlation with green consumer behavior. Whereas [11] believe that individuals will look for environmentally friendly products because they assume they will be healthy, live in high quality, and preserve the environment. Hypothesis 2 is accepted. It 
states that there is a significant influence of green consumer behavior on green purchase intention. The more people's interest in choosing environmentally friendly products, the higher the green purchase intention towards environmentally-friendly AQUA products. Before purchasing a product, the consumer always evaluates many things about the product.

From five indicators built to explain the green purchase intention variable, only two indicators can measure latent variables, people interested in finding information about environmentally friendly products and people who consider purchasing environmentally friendly products. Hypothesis 3 , which proposed that there is an effect of green marketing mix on green purchase intention, is rejected with an estimated value of 0.255 with a probability value of 0.253 . This means that the green marketing mix in green products, green prices, green places, and green promotions does not affect people's purchasing interest in environmentally friendly products. This study's results are in line with the research by [30], which explains that green advertising does not affect green purchase intentions. However, green products have a significant effect on green purchase intentions. This study's results are not the same as [31], which states that the green marketing mix has a positive and. a significant effect

Hypothesis 4 is accepted. It states that there is a significant effect of green consumer behavior on green purchase decisions. The more people's interest in choosing environmentally friendly products, the higher the green purchase decision for environmentally friendly products. The more people's interest in environmentally friendly products, the higher their decision to buy environmentally friendly products. Likewise, the more interest in environmentally friendly products, the higher the chance to buy environmentally friendly products. Consumer purchasing behavior is a way for consumers to buy something that they need or want. Before purchasing a product, the consumer always evaluates many things about the product. Green consumer behavior reflects the behavior that is influenced by their concern for the environment. This is reflected by how the individual is looking for, buys, uses, evaluates, and disposes of the product [21].

From the five indicators built to explain the green purchase decision variable, only two can measure latent variables. Those indicators are "people are buying environmentally friendly products according to the products' quality," and "people are buying environmentally friendly products that are better than the competitors' products." Results show that hypothesis 5 is accepted. It states that there is a significant effect of green purchase intention on green purchase decisions. The more people's interest in finding information about environmentally friendly products and the more they consider to buy environmentally friendly products, the more they will decide to buy the products that have the best quality among the others. Customers will not buy environmentally friendly products if the product has low quality and high prices. The past experiences will also shape the purchasing behavior of environmentally friendly products from the customers. This means that the price is vital in environmentally friendly purchasing behavior along with the product quality [28].

\section{Implications and Recommendations}

Consumers are increasingly aware of the environmental impacts arising from using plastic bottled water. Companies must pay attention to consumers' environmental needs and desires and try to satisfy them by designing environmentally friendly marketing activities. As the highest market share holder in bottled drinking water, AQUA should pay attention to its 
products by promoting environmentally friendly products because people are increasingly considering to buy products that are environmentally friendly in all aspects.

\section{References}

[1] J. P. Govender and T. L. Govender, "The influence of green marketing on consumer purchase behavior," Environ. Econ., 2016, doi: 10.21511/ee.07(2).2016.8.

[2] G. F. Mantiaha, "The Influence of Green Marketing On Consumer Buying Behaviour," J. EMBA, vol. 4, no. Juni, pp. 58-067, 2016.

[3] H. R. Kordshouli, A. Ebrahimi, and A. A. Bouzanjani, "An analysis of the green response of consumers to the environmentally friendly behaviour of corporations," Iran. J. Manag. Stud., vol. 8, no. 3, pp. 2345-3745, 2015, [Online]. Available: http://ijms.ut.ac.ir/.

[4] V. Chittipaka and S. Shaik, "Changing Role of Green Marketing Mix in Consumer Buying Behaviour-an Empirical Investigation,” Asia Pacific J. Mark. Manag. Rev., vol. 2, no. 11, pp. 130 141, 2013, [Online]. Available: https://www.researchgate.net/publication/293823445.

[5] F. Z. Sheikh, A. A. Mirza, A. Aftab, and B. Asghar, "Consumer Green Behaviour Toward Green Products and Green Purchase Decision,” Int. J. Multidisplinary Sci. Eng., pp. 1-9, 2014.

[6] "Titik Persentase Distribusi F," pp. 0-5.

[7] L. Alfansi, M. Nanere, F. T. Atmaja, and C. D’Souza, "Empirical Evidence on the Antecedences of Customer Loyalty," vol. 7, no. 2, pp. 1-16, 2557.

[8] M. J. Polonsky, "An Introduction To Green Marketing," Electron. Green J., 1994, doi: $10.5070 / \mathrm{g} 31210177$.

[9] M. J. Polonsky, "Green marketing," in Sustainable Solutions: Developing Products and Services for the Future, 2017.

[10] K. Peattie and M. Charter, "Green marketing," Mark. B., vol. 12, pp. 726-756, 2012, doi: 10.9774/gleaf.978-1-907643-21-7_17.

[11] J. A. Ottman, E. R. Stafford, and C. L. Hartman, "Avoiding green marketing myopia: Ways to improve consumer appeal for environmentally preferable products," Environment, 2006, doi: 10.3200/ENVT.48.5.22-36.

[12] A. Davari and D. Strutton, "Marketing mix strategies for closing the gap between green consumers' pro-environmental beliefs and behaviors," J. Strateg. Mark., 2014, doi: 10.1080/0965254X.2014.914059.

[13] A. Diglel and R. Yazdanifard, "Green Marketing: It's Influence on Buying Behavior and Attitudes of the Purchasers towards Eco-Friendly Products," Glob. J. Manag. Bus. Res., 2015, doi: 10.5964/jspp.v2i1.299.

[14] J. Moisander, "Motivational complexity of green consumerism,” Int. J. Consum. Stud., 2007, doi: 10.1111/j.1470-6431.2007.00586.x.

[15] M. Abzari, F. Safari Shad, A. A. A. Sharbiyani, and A. P. Morad, "Studying the effect of green marketing mix on market share increase," Adv. Environ. Biol., 2013.

[16] S. Istantia, S. Kumadji, and K. Hidayat, "Pengaruh Green Marketing Terhadap Citra Merek Dan Keputusan Pembelian (Survei pada Pengguna Produk Ramah Lingkungan Lampu Philips LED di Perum ...," J. ..., 2016.

[17] N. K. Sharma, S. P. Tiwari, K. Tripathi, and A. K. Rai, "Sustainability and cyanobacteria (bluegreen algae): Facts and challenges,” Journal of Applied Phycology. 2011, doi: 10.1007/s10811-0109626-3.

[18] N. Ansar, "Impact of green marketing on consumer purchase intention," Mediterr. J. Soc. Sci., 2013, doi: 10.5901/mjss.2013.v4n11p650.

[19] M. G. Mayorga et al., “No 主観的健康感を中心とした在宅高齢者における 健康関連指標に関 する共分散構造分析Title,” J. Chem. Inf. Model., vol. 6, no. 2, pp. 1689-1699, 2016, doi: 10.1017/CBO9781107415324.004. 
[20] J. Pickett-Baker and R. Ozaki, "Pro-environmental products: Marketing influence on consumer purchase decision," Journal of Consumer Marketing. 2008, doi: 10.1108/07363760810890516.

[21] R. Siringi, "Determinants of Green Consumer Behavior of Post graduate Teachers," IOSR J. Bus. Manag., vol. 6, no. 3, pp. 19-25, 2012, doi: 10.9790/487x-0631925.

[22] W. B. Dodds, K. B. Monroe, and D. Grewal, "Effects of Price, Brand, and Store Information on Buyers' Product Evaluations," J. Mark. Res., 1991, doi: 10.2307/3172866.

[23] A. R. Maatoofi and K. Tajeddini, "Effect of Market Orientation and Entrepreneurial Orientation on Innovation Evidence from Auto Parts Manufacturing in Iran,” J. Manag. Res., vol. 11, no. 1, pp. 20-30, 2011, doi: 10.1108/03090560910923292.

[24] A. Ali, A. Khan, I. Ahmed, and W. Shahzad, "Determinants of Pakistani consumers' green purchase behavior: Some insights from a developing country,” Int. J. Bus. Soc. Sci., 2011.

[25] P. Hartmann and V. Apaolaza-Ibáñez, "Consumer attitude and purchase intention toward green energy brands: The roles of psychological benefits and environmental concern,” J. Bus. Res., 2012, doi: 10.1016/j.jbusres.2011.11.001.

[26] N. Koenig-Lewis, A. Palmer, J. Dermody, and A. Urbye, "Consumers' evaluations of ecological packaging - Rational and emotional approaches," J. Environ. Psychol., 2014, doi: 10.1016/j.jenvp.2013.11.009.

[27] A. Paladino and S. Ng, "An examination of the influences on 'green' mobile phone purchases among young business students: an empirical analysis," Environ. Educ. Res., 2013, doi: 10.1080/13504622.2012.687044.

[28] C. D’Souza, M. Taghian, P. Lamb, and R. Peretiatkos, "Green products and corporate strategy: an empirical investigation,” Soc. Bus. Rev., 2006, doi: 10.1108/17465680610669825.

[29] M. Wheeler, A. Sharp, and M. Nenycz-Thiel, "The effect of 'green' messages on brand purchase and brand rejection,” Australas. Mark. J., 2013, doi: 10.1016/j.ausmj.2013.02.007.

[30] J. L. Kong Wilson, Harun Amran, Sulong Rini Suryati, "International Journal of Asian Social Science THE INFLUENCE OF CONSUMERS' PERCEPTION OF GREEN PRODUCTS Amran Harun Rini Suryati Sulong Jaratin Lily Contribution / Originality,” Asian Soc. Sci., vol. 4, no. 8, pp. 924-939, 2014.

[31] T. O. Mahmoud, "Impact of green marketing mix on purchase intention," Int. J. Adv. Appl. Sci., vol. 5, no. 2, pp. 127-135, 2018, doi: 10.21833/ijaas.2018.02.020. 